\title{
IVAN HAVEL A FILOSOFIE
}

Nedávno zesnulý Ivan M. Havel (1938-2021) nebyl filosof. Vzpomínka na něho a zamyšlení nad jeho odkazem na stránkách filosofického časopisu nicméně není od věci, a to přinejmenším z následujících tří důvodů: (1) Ivan Havel měl dosti zajímavou a důležitou úlohu $v$ nezávislém myšlení předlistopadové éry (tedy $\mathrm{v}$ prostř̌edí, z něhož pochází i přítomný časopis), a to v bytech i v tzv. „,̌edé zóně“, (2) jeho vlastní odborná práce v rámci informatiky se od jisté doby zaměřovala na umělou inteligenci a kognitivní vědy, které s filosofíi sousedí, a (3) Ivan Havel byl důležitou a vlivnou postavou v diskusi o vztahu filosofie a humanitních disciplín $\mathrm{k}$ vědě a o povaze vědeckosti vůbec. Zmíněné tři ohledy se nicméně všelijak prolínají a proplétají, a snad bude pro čtenářovu (i autorovu) orientaci nejsnazší rozčlenit látku tak, že nejprve bude pojednán Ivan Havel jako výkonný vědec-informatik, pak Ivan Havel jako zájemce o filosofii a katalyzátor filosofické komunikace a nakonec Ivan Havel jako bojovník proti „scientismu“, popularizátor vědy a prorok transdisciplinarity.

\section{Vědec-informatik}

Je snadno představitelné, že za trochu jiných okolností by Ivan Havel zůstal výborným mainstreamovým vědcem (nejspíš s širokým rozhledem a chutí diskutovat, takoví už mnozí vědci jsou). Google Scholar mu připisuje devět set třicet tři citací, přičemž $\mathrm{v}$ jeho stovky položek čítající bibliografii generují nejvíce citací tři články z jeho podstdoktorandských let 1972-1974. Havel studoval střední i vysokou školu se zpožděním večerně při zaměstnání (z tzv. kádrových důvodů musel jako patnáctiletý do učení a pak do navazující práce), ale vzdělání a věda ho lákaly o to víc a náhlé svobody pražského jara využívá k nástupu do doktorského studia na University of California v Berkeley: koncem roku 1971 se vrací s doktorátem a nastupuje do Ústavu teorie informace a automatizace (ÚTIA) na Československé akademii věd.

Doktorát a bezprostředně následující práce spadají do teorie formálních jazyků a konečných automatů, jak ji založil v padesátých letech geniální Noam Chomsky. Bylo jistě těžké udržet kontakt se špičkovým výzkumem v této oblasti bez přímého styku se světovou vědou - možnost vyjíždět na konference a stáže, za normalizace obecně značně byrokraticky sešněrovaná, po vzniku Charty 77 nadobro zmizela. Ivanův poslední hojně citovaný článek z této oblasti je z roku 1979 - koncem téhož roku ztrácí zaměstnání v ÚTIA (opakovaně odmítal podepsat odsouzení Charty 77) a hledá si práci jako programátor.

Programovat samozřejmě uměl výborně, už roku 1966 byl programátorem v rámci trojčlenného týmu, který dal světu metodu GUHA, dodnes užívanou techniku pro data-mining, tedy softwarové nacházení srozumitelných pravidelností, vzorců a zákonitostí ve větším množství dat. Během let v ÚTIA se od čistě akademického oboru formálních jazyků a konečných automatů posouval směrem $\mathrm{k}$ robotice a umělé inteligenci a v osmdesátých letech vskutku programoval robo- 
tické aplikace v hutnictví (jako zaměstnanec družstva invalidů Meta). Říkám to vše i proto, že v posledních desetiletích býval Ivan Havel občas líčen jako odpůrce mainstreamové vědy a někdy dokonce jako osoba pro ni nebezpečná. Pokud něčím takovým byl (uvidíme, že spíše ne), tedy rozhodně jakožto kompetentní insider, a ne jakožto popletený outsider.

\section{Zájemce o filosofii a katalyzátor filosofické komunikace}

Do kontaktu s filosofií přivedly Ivana Havla jeho nenasytná zvídavost i solidarita s vězněným bratrem. Kolem poloviny sedmdesátých let začal docházet do filosofických salonů Dani Horákové, které pořádala u sebe v Pařížské ulici a o nichž se Ivan doslechl od svého bratra. Líbily se mu zřejmě dost na to, aby po jejich skončení rozběhl vlastní filosoficko-všehochut'ový salon, tzv. Pondělky, do něhož přešla přinejmenším část osazenstva z Pařǐžské. Po nepravidelnějších počátcích se konávaly každé druhé pondělí zhruba od konce záríi do května nebo června, a to od listopadu 1977 až do prosince 1989, se zhruba roční přestávkou v letech 1986-1987, kdy policie začala zadržovat přednášející, a v bytě pak probíhala přestavba.

Ve srovnání se soustř̌eděnou prací v bytových seminárích nemohly jednorázové přednášky či diskuse na Pondělcích jít do hloubky: sehrávaly ale důležitou úlohu v tom, že se u nich setkávali různě orientovaní myslitelé a vzdělaní laici, díky čemuž bývaly teorie, které třeba vypadaly výborně v uzavřeném prostředí sympatizujících zájemců, konfrontovány s otázkami a námitkami zvenku - a někdy se ukazovalo, že s nimi mají nesnáz. Takovou roli nesympatizujícího čtenáře fenomenologických textů podnětně sehrával zejména Pavel Materna (některé Pondělky byly rovnou plánovány jako panelové diskuse). Člověk tu mohl potkat další myslitele vedle těch, u kterých už studoval, slyšet o dalších tématech a setkat se s dalšími přístupy, docela jako na konferencích za svobodnějších poměrů. Př́ležitostně se mohl člověk i rozhodnout, že u někoho, koho takto potkal, v budoucnu určitě chce studovat. Tato funkce Pondělků byla v Praze jedinečná a značně přínosná - samozřejmě, příslušníci různých filosofických společenství se setkávali i na jednorázových přednáškách zahraničních hostů, ale tam šlo primárně o něco jiného než o vzájemnou konfrontaci. ${ }^{1}$

Vedle pořádání bytového filosofického salonu byl Ivan Havel v osmdesátých letech také hvězdou ,šedé zóny“, již pro naši potřebu můžeme definovat jako události, které byly tím či oním režimním orgánem schválené a leckdy i veřejné, ale u nichž bylo jasné, že je třeba o nich nemluvit nebo mluvit jen málo a opatrně, protože kdyby se o nich mluvilo moc, pravděpodobně by se o nich dozvěděly

1 Nejčastěji přednášeli Zdeněk Neubauer, sám hostitel a Radim Palouš, hned po nich Jan Sokol, Pavel Materna, Jiří Fiala a Martin Palouš. Opakovaně přednášeli i Jiří Němec, Petr Rezek, Zdeněk Pinc, Daniel Kroupa, Ivan Chvatík či autor této vzpomínky, spíše vzácně zavítali i Stanislav Sousedík, Ladislav Hejdánek, Tomáš Halík nebo zahraniční hosté. Úplný přehled viz J. Wohlmuth Markupová, Ivan M. Havel. Od Puzuka k Sakatekovi (1938-1989), Praha 2017, str. 199-207. 
nějaké nebezpečnější složky tehdejšího režimu, překazily by je a způsobily neprŕjjemnosti jejich organizátorům. Sám jsem od roku 1980 docházel do výběrového semináře prof. Katětova Matematické metody v psychologii (na MFF UK) a na přednáškovou řadu pro veřejnost Filozofické otázky kybernetiky - tehdy v Ústředním domě armády (ÚDA) v Dejvicích, přednášky pak byly po několika letech přesunuty do ústředí Československé vědecko-technické společnosti na Novotného lávce. U Katětova se scházela menší noblesní společnost, nějakých osm až dvanáct lidí: k pravidelným účastníkům patřili Ivan Havel, Zdeněk Neubauer, Jiř́i Fiala či Cyril Höschl a přednášelo se a diskutovalo na širokou škálu témat, v nichž ale skoro vždy nějak figurovaly lidská mysl nebo matematika (často obojí).

Čtenáře Reflexe - stejně jako tehdy mě - budou možná více zajímat Filozofické otázky kybernetiky, kde Ivanu Havlovi občas sekundoval Zdeněk Neubauer. Středně velká posluchárna bývala plná, chodilo přes padesát lidí a Havel vycházel z tehdy nové Hofstadterovy knihy Gödel, Escher, Bach. The Eternal Golden Braid (1979). Bohatý a často zábavný materiál z knihy podkládal důkladnějšími výklady z matematiky, logiky a informatiky, přičemž hlavním poselstvím přednáškové řady bylo: když nezůstanete u povrchních samozřejmostí a budete kutat hlouběji, pak se - budete-li dostatečně přesní a důslední - dosti často dostanete do situace, kde zůstává rozum stát (aporií) a kde jste z toho vedle (paradoxů).

Hofstadter sám hovoří poněkud vágně o strange loop, podivném zacyklení, a Havel tyto myšlenky rozvíjel, aniž by došel k nějakému jasně formulovatelnému metavýsledku - s ohledem na vypracovanost a jasnost dílčích př́íkladů kontrastující s absencí či vágností pozitivních závěrů jeho počínání mohlo připomínat pozdního Wittgensteina. Havel si hodně všímal autoreference jako stavební součásti mnoha známých paradoxů, počínaje paradoxem lháře, a bavilo ho nacházet nebo vymýšlet nové („,Připomíná vám tato věta Agathu Christie?“). Věděl samozřejmě o Russellově návrhu autoreference omezit (např. v teorii typů), ale na př́kladu Gödela ukazoval, že by bylo nešt'astné se jí systematicky vyhýbat, protože může skýtat jinak nedosažitelný, mocný myšlenkový nástroj.

Ještě zajímavější než autoreferenční paradoxy byly aporie, v nichž se ocitá např́íklad pozorovatel Escherových grafik. Jedna intuice tu naráží na druhou a je jí eliminována, aby pak znovu povstala z popela při pokusu druhé, dočasně vítězné intuice o ovládnutí celého pole - máme tu na mysli díla jako Drawing Hands nebo Waterval.Zde nabízel Neubauer svého druhu výtěžek, když opakovaně a s velkým důrazem hovořil o nemožnosti dosáhnout "God-like position“ (když jsem později hledal, co mohlo být předlohou tohoto trochu neohrabaného pseudocitátu, jako nejpravděpodobnější kandidát se ukázal Putnamův „God's eye point of view").

Ve zpětném pohledu mi připadá, že tyto Havlovy přednášky měly - přinejmenším na mě - značný formativní účinek: nabízely způsob, jak přistupovat ke zvláštním aporetickým strukturám u Huma, starověkých skeptikủ, Descarta či Platóna i k některým důležitým aporiím v systematické filosofii (jako je svoboda/determinace, realismus/idealismus apod.). Není tu dost místa na podrobnější 
výklad, ale čtenář, kterého by uvedené téma zajímalo, nalezne více zejména v mém článku Jak jsem se stal pluralistou ... a jak se to projevuje. ${ }^{2}$ Ukazuji tam, jak se tento Havlem inspirovaný pluralismus stává nepostradatelným pracovním nástrojem jak v řadě závažnějších úseků dějin filosofie, tak při filosofické práci samé (a ukazuji také jeho nepochopení v určité dobové verzi české tzv. postmoderny).

Důležitou a donedávna málo známou filosofickou aktivitou Ivana Havla v letech 1979-1982 bylo jeho psaní vězněnému bratrovi. Ivanovi s ním pomáhají i jeho noví filosofičtí přátelé, především Zdeněk Neubauer, Jiří Němec a Radim Palouš (k němuž také Ivan dochází do tzv. Kampademie, uzavřené filosofické společnosti, jejíž setkání probíhala jednou za čtrnáct dní v pondělí a střídala se s pondělním Havlovým salonem). Ivan často doslova opisuje stránky textů, které od nich dostal, tedy jejich vlastní úvahy, kratší překlady (např́íklad z Heideggera či Levinase) a reakce na Václavovy dopisy, ale dosti obsáhle a zajímavě píše i sám: dopisy se základním komentářem vyšly roku 2010 péčí Jana M. Hellera a Martina C. Putny pod názvem Dopisy od Olgy. ${ }^{3}$

Sluší se prripomenout i to, že Ivan Havel se po uvěznění svého bratra a odjezdu Dani Horákové do Německa stává řídící postavou samizdatové Edice Expedice, kterou Václav Havel s Daňou Horákovou založili a v níž vycházely i filosofické a filosoficky relevantní texty.

\section{Bojovník se „scientismem“, prorok transdisciplinarity, organizátor a popularizátor}

Po zhruba sedmiměsíční epizodě v Občanském fóru se Ivan Havel roku 1990 stává zakládajícím členem a ředitelem Centra pro teoretická studia Univerzity Karlovy (CTS) a šéfredaktorem kvalitního časopisu pro popularizaci vědy zvaného Vesmír, v němž svého času publikoval i Patočka. K obojímu byl výborně disponován: nejpozději od berkeleyského doktorského studia pravidelně četl americký časopis pro popularizaci vědy Scientific American ${ }^{4}$ a spoustu výborných popularizujících bestsellerů ze všech oblastí věd, takže se v nejnovější vědě výtečně orientoval, byl známou osobností s mezinárodními styky a přívětivým diskutérem. Přesto však na CTS i na Vesmír pohlížela část české vědecké veřejnosti s podezřením a někdo možná i s odporem.

To podezření a ten odpor byly reakcí na podivínské výpady obou Havlů proti „scientismu“, inspirované pravděpodobně především Zdeňkem Neubauerem.

2 J.Moural, Jak jsem se stal pluralistou ... a jak se to projevuje, in: Ostium, 3, 2019, str. 1-16, dostupné online: https://ostium.sk/language/sk/jak-jsem-se-stal-pluralistou -a-jak-se-to-projevuje/ (navštíveno 1. srpna 2021).

3 Ivan M. Havel a kol., Dopisy od Olgy, Praha 2010.

4 Vzpomínám, s jakým potěšením publiku v ÚDA sděloval, že Hofstadterův šíríící se věhlas dokládá i to, že tradiční rubriku Martina Gardnera Mathematical Games v časopise Scientific American po třiceti letech nahradila nová Hofstadterova rubrika Metamagical Themas. 
Václav Havel ve svém česky psaném projevu pro americký Kongres mylně vycházel z toho, že tento český diskurs je mezinárodně srozumitelný, a tehdejší Havlův překladatel (údajně Michael Žantovský) s katastrofálními následky přeložil Havlovo „scientisté“ jako „scientists“ (neboli „,vědci“), takže velká část světové veřejnosti, která by na Havla byla ráda pohližela se sympatiemi, se cítila nucena se od něho distancovat nebo ho přijímat pouze selektivně a s výhradami. Dosti podobně, i když s daleko menším a pouze lokálním dopadem, se tehdy s despektem o scientismu vyjadřoval i Ivan Havel a některé další postavy spjaté s CTS (vedle již zmíněného Zdeňka Neubauera třeba Dušan Třeštík).

Dnes je tato epizoda českých intelektuálních dějin již více méně zapomenuta a věřím, že k tomu prrispěl i můj článek z roku 1999, v němž jsem ukázal, že svérázný český pojem scientismu je v cizině prakticky neznámý a že jeho čeští zastánci jej užívají (a tedy nejspíš i myslí) dosti zmateně. ${ }^{5}$ Někdy v této době byly v CTS zavedeny pondělní odpolední semináře a několik semestrů jsem tam vedl četbu Poppera a Kuhna, která tehdy - v součinnosti s prací Zdeňka Konopáska na poli „,science studies“ neboli vědozpytu a v diskusích s Bruno Latourem a dalšími návštěvníky - vedla k oživení prèedtím skomírající české filosofie vědy. Jedním z následků těchto seminářù jsou i záchranné nové překlady základních Popperových a Kuhnových prací, které od té doby postupně vycházejí.

Ivan Havel měl samozrejmě vědu ohromně rád: byl schopen do ní i nikoli nevýznamně přispívat a jako určující četbu svého dětství uvádí krásný životopis Marie Curie-Skłodowské od její dcery ${ }^{6}$ (obsahující působivé pasáže, v nichž se mladá polská intelektuálka vyznává z nadšení pro pozitivismus). ${ }^{7}$ Byl nicméně loajální i k filosofických druhům svých filosofických začátků, v lepším i horším. Transdisciplinárně orientované CTS bylo přesto výtečnou školou a nejspíš jí dosud je, i když některé velké postavy prvních dvaceti let je a bude těžké nahradit. R. I.P.

Josef Moural

5 J. Moural, Scientismus. Osudy jednoho pojmu (u nás $i$ v cizozemí), in: Kritický sborník, 18, 4, 1998-1999, str. 7-18. Článek je zestručněným shrnutím několikahodinové diskuse, kterou jsme s Ivanem vedli na výletě v lesích nad Slapskou přehradou na jaře 1998 .

6 Viz V. Šlajchrt, Když, se internet zamyslí, in: Respekt, 9. února 2008, dostupné online: https://www.respekt.cz/tydenik/2008/7/kdyz-se-internet-zamysli (navštíveno 1. srpna 2021).

7 E. Curieová, Paní Curieová, přel. E. Sgallová, Praha 1964, str. 50. 